\title{
Ontogenetic shape changes and sexual dimorphism in Aegla marginata Bond-Buckup and Buckup, 1994
}

\author{
CAROLINA L. ADAM, MURILO Z. MAROCHI and SETUKO MASUNARI \\ Departamento de Zoologia, Universidade Federal do Paraná, Avenida Coronel \\ Francisco Heráclito dos Santos, 100, 81531-980 Curitiba, PR, Brazil
}

Manuscript received on June 6, 2017; accepted for publication on December 8, 2017

\begin{abstract}
A study on relative growth, sexual dimorphism and ontogenetic trajectory was carried out in a population of the aeglid Aegla marginata coming from Barrinha River, Iguape River Basin, Tunas do Paraná, Paraná State, Brazil. The size the of morphological sexual maturity was estimated for males and females. The analysis of sexual dimorphism and ontogenetic trajectory were performed using geometric morphometric technique. Males reach maturity with $10.58 \mathrm{~mm}$ of carapace length (CL) and females with $10.38 \mathrm{~mm}$ CL. Sexual size dimorphism was only visible among adults, with males reaching larger sizes. This is probably related to the reproductive strategy of males. However, sexual shape dimorphism was found for both juveniles and adults: the posterior region of the carapace was wider in females. As the contrast of this feature was stronger in adults, it can be considered that large abdomen is advantageous for egg incubation. The allometric trajectories of juveniles presented similar directions, becoming divergent during the adult phase. The shape variation in A. marginata occurred gradually throughout its development, with no abrupt transformation upon reaching sexual maturity. The reproductive adaptation is the main reason for the morphological variation within populations of $A$. marginata.
\end{abstract}

Key words: allometry, relative growth, sexual dimorphism, shape.

\section{INTRODUCTION}

Allometry can be characterized as the shape variation of body structures influenced by the variation of their size or the total size of the organism (see revision in Mitteroecker et al. 2013). The study of this variation during the development of an individual, or a group of individuals, is called ontogenetic allometry (Klingenberg 1996). One method to evaluate the average growth of

Correspondence to: Carolina de Lima Adam

E-mail: caroladam27@hotmail.com a population is to obtain morphometric data from animals of all life stages, divided into size subgroups (Cock 1966). The same method can be used to plot the allometric trajectory of a population (Klingenberg 2016).

One of the causes for allometric variation in the body plan of organisms is sexual dimorphism, a common and widely studied feature in the animal kingdom (Shine 1989, Fairbairn 1997). It may arise as a result from pressure exerted by natural or sexual selection (Fairbairn 1997). In most anomuran and brachyuran species, females presents an enlarged 
abdomen, which provides space to accommodate the egg mass (Barría et al. 2011, Marochi et al. 2016). Regarding sexual selection, in some species males can develop structures used as weapons during intra sexual combats or to attract females, resulting in an advantage to obtain partners and, consequently, improving reproductive success (Shine 1989, Hedrick and Temeles 1989). In crustaceans, a clear example of sexual dimorphism caused by sexual selection is in fiddler crabs, in which males present highly pronounced heterochely (Crane 1966). Among aeglid crabs, male chelipeds show positive allometric growth (see Oliveira and Santos 2011 for review), which can be considered a characteristic to favor males with larger chelipeds.

The occurrence of sexual shape and size (size variation between sexes) dimorphism in aeglid crabs is widely documented in the literature (Barría et al. 2011, Giri and Collins 2004, Collins et al. 2008), including $A$. marginata (Trevisan et al. 2012). This dimorphism was associated with the development of secondary sexual characters, suggesting that the variation in carapace shape emerges only after sexual maturation.

The knowledge of the time in which sexual dimorphism appears during the ontogenetic development can provide subsidies for future studies testing hypotheses related to sexual selection and shape evolution in Aeglidae. The general pattern of aeglids and other decapods is that sexual differentiation occurs only after puberty molt (change from juvenile to adult phase) (Hartnoll 1974, 2001). However, these morphological changes were mainly evaluated through classic (i.e., linear) morphometric methods (Hartnoll 2001), especially with relative growth analysis (used to compare the differential growth rate of body structures), which do not include shape information (Oliveira and Santos 2011). Our aim was to test the sexual size and shape dimorphism on the carapace of $A$. marginata, also analysing the variations in shape during ontogeny and comparing the allometric trajectories of both life stages.

\section{MATERIALS AND METHODS}

\section{STUDY AREA}

The animals were obtained from Barrinha River $25^{\circ} 00$ '38.3” S 4904'46.7” W, a tributary of Ribeirão Grande River, Ribeira do Iguape River Basin, in the municipality of Tunas do Paraná, Paraná State, Brazil. The collection site presented marginal vegetation and a bottom composed of gravel of different sizes and sandy patches; the gravel predominates in the central canal of the river, while the sand predominates in the margins.

The collections were carried out between August, 2015 and March, 2016 with traps and hand nets. The traps were baited with beef liver and left in the river overnight, and the sampling effort was 60 minutes. The animals were preserved in $75 \%$ ethanol. Aeglids were sexed based on the presence of pleopods in females and absence in males. Animals with less than $6 \mathrm{~mm}$ of carapace length (CL) were sexed under stereomicroscope, examining the presence (in females) or absence (in males) of gonopore(s) in the third pair of pereiopods. Furthermore, aeglids smaller than 4 mm CL were considered sexually undifferentiated juveniles.

\section{RELATIVE GROWTH}

A total of 168 males, 126 females and 16 juveniles of undifferentiated sex (included into males' and females' groups) were analysed. We obtained body dimensions from aeglids of both sexes, with a digital caliper $(0.01 \mathrm{~mm}$ precision): carapace length (CL) measured from the distal apex of the rostrum to posterior margin of the carapace; carapace width $(\mathrm{CW})$, between the lateral margins at its widest dimension; abdomen width (AW), between the lateral margins at its widest dimension; length of the major (LMA) and minor (LMI) cheliped propodus, from the apex of pollex to the posterior end of the outer margin; and width of major 
(WMA) and minor (WMI) cheliped propodus at their widest dimension. Three adult males and two juvenile females were eliminated from the analysis due to damaged rostra. Animals smaller than $6 \mathrm{~mm}$ CL were measured under Dino-Lite Pro AM413 digital microscope.

We considered $\mathrm{CL}$ as an independent variable and the remaining as dependent variables, based on Huxley (1950). The relative growth was tested using the allometric equation $y=a x^{b}$, where $x$ represents the independent variable (CL), $y$ the dependent variables, $a$ the slope of the lines and $b$ the allometric coefficient. This equation was linearized to $\log \mathrm{y}=\log \mathrm{a}+\mathrm{b} \log \mathrm{x}$. The allometric coefficient $(b)$ was tested with a $t$ test, against the null hypothesis of isometry $(b=1)$. To test the straight lines equality of the life stages, among slopes and intercepts (juvenile and adult), we used an analysis of covariance (ANCOVA, $\alpha=5 \%$ ) by applying the linear measurements, except CL, as covariables (Sokal and Rohlf 1979). The software REGRANS (Pezzuto 1993) was used in order to adjust the lines and to verify the presence of either one or two regression lines, and thus the inflection point that indicates the puberty size, while the remaining analyses were performed with the software BioEstat 5.0 (Ayres et al. 2007).

\section{GEOMETRIC MORPHOMETRICS (GM)}

The animals were photographed in their dorsal view with a digital camera Fujifilm FinePix HS10, 10 megapixels. All photos were obtained from the same distance $(10 \mathrm{~cm})$ and with the same zoom. Eleven anatomical landmarks were established in the carapace (Figure 1) using the software TpsDig2 (Rohlf 2010). The digitalization of landmarks was carried out by the same researcher in three replicates, to verify possible errors. A Generalized Procrustes Analysis (GPA) was performed to extract the information regarding scale, position and orientation. Animal size was described by the centroid size, whose value is calculated from the square root of the sum of the square distances of the anatomical landmarks to the centroid (Adams et al. 2004). Shape is defined as all the geometric information that remains when location, scale and rotational effects are filtered out from an object (Kendall 1977). The shape analyses were performed in the software MorphoJ version 2.16 (Klingenberg 2011) and the statistical analyses in the R environment version 2.11 (R Development Core Team 2008). For the GM analyses a total of 68 adult males, 57 adult females, 97 juvenile males and 63 juvenile females were analysed. The life stages were determined from the size at the onset of morphological sexual maturity obtained in the relative growth analysis. The juveniles of undifferentiated sex were excluded in this analysis, as well as the animals with damaged carapaces.

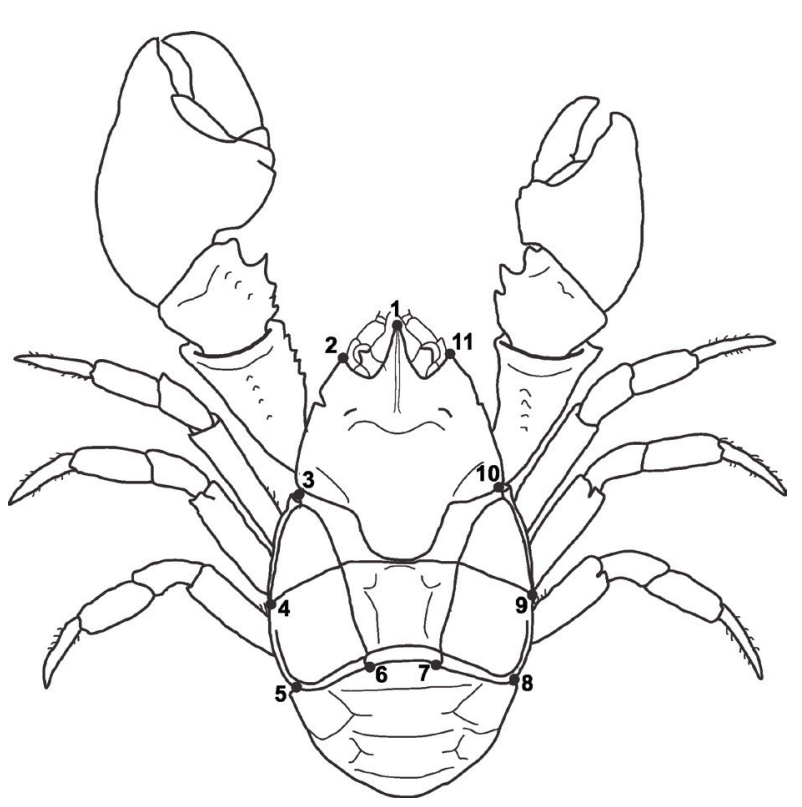

Figure 1 - Aegla marginata. Position of the anatomical landmarks established on the dorsal surface of the carapace. 1: tip of the rostrum; 2 and 11: tip of the anterolateral spines; $\mathbf{3}$ and 10: limits between the $3^{\text {rd }}$.hepathic lobe and the epibranchial tooth; $\mathbf{4}$ and 9: intersection between the posterior branchial line and the posterior "linea aeglica lateralis"; 5 and 8: Posterolateral vertex of carapace; and $\mathbf{6}$ and 7: posterior end of the longitudinal dorsal line. 


\section{SEXUAL DIMORPHISM}

The sexual dimorphism in the carapace size among juveniles (between sexes) and among adults (between sexes) was tested with the $t$ test for paired samples using the logarithmized centroid size. The sexual dimorphism in the carapace shape was tested with a multivariate regression of the symmetrical components of the shape (Procrustes coordinates) on centroid size (Klingenberg 2016). A Principal Component Analysis (PCA) was performed to determine the percentage of explanation relative to each principal component (PC) over the total variation. The principal component scores were used as new variables to characterize the shape. This approach allowed the scores to be used as independent variables and also to reduce the dimensionality of the data (Klingenberg and Monteiro 2005). Differences in shape between sexes were evaluated with a Discriminant Analysis (DA) with permutation and cross-validation test, to determine the correct classification percentage, using the regression residues (Viscosi and Cardini 2011). To describe shape in all analyses we used partial warps.

\section{ONTOGENETIC TRAJECTORY}

The variation in the carapace shape during development (ontogenetic allometry), was analysed with a multivariate regression of the Procrustes coordinate matrix against the log of the centroid size, that was performed separately for each sex. The level of significance of the regressions was tested with a permutation test. To verify if the allometric trajectories of males and females differed from the pairs of random vectors, we compared the angles of the regression vectors of each sex at each life stage (Drake and Kilgenberg 2008, Klingenberg 2016). A total of 68 adult males, 57 adult females, 97 juvenile males and 63 juvenile females were analysed. Juveniles of undifferentiated sex were excluded from this analysis.

\section{RESULTS}

\section{RELATIVE GROWTH}

All relations between the dependent variables and the CL showed positive allometry, except males' CW x CL for juveniles (negative allometry) and adults (isometry) (Table I). The inflection point between the juvenile and adult males in the scatter plot occurred at $10.58 \mathrm{~mm} \mathrm{CL}$ (Fig. 2a), and that of females' at $10.35 \mathrm{~mm} \mathrm{CL}$ (Fig. 2b). The smallest ovigerous female in the population measured $11.80 \mathrm{~mm} \mathrm{CL}$, which confirms the suitability of the inflexion point obtained for females as an estimative of their onset of sexual morphological maturity.

There was a significant difference in both the intercept (a) ( $<$ 0.0001) and the slope (b) (p $<0.0001$ ) of the straight lines for juveniles and adult males in the LMA x CL scatter plot. For females, there was a significant difference in the intercept ( $p$ $<0.0001)$, but not in the slope ( $\mathrm{p}=0.0876)$, of the straight lines for juveniles and adults in the AW $\mathrm{x}$ CL scatter plot (Table II).

\section{SEXUAL DIMORPHISM}

There was a significant difference in the carapace size (centroid size) of adult males and females $(t=$ $-2.4423, \mathrm{p}=0.0162$, mean $\pm \mathrm{SD}$ males $=16.18 \pm$ $3.45 \mathrm{~mm}$, mean \pm SD females $=14.96 \pm 2 \mathrm{~mm}$ ), but not for juveniles $(t=0.9376 ; \mathrm{p}=0.3498$; mean \pm SD males $=11.65 \pm 3.30 \mathrm{~mm}$; mean \pm SD females $=12.13 \pm 2.93 \mathrm{~mm}$ ). On the other hand, there was a significant difference in the carapace shape between the sexes in both juvenile $(\mathrm{p}<0.001$, Procrustes distance $=0.0066)$ and adult $(\mathrm{p}<0.001$, Procrustes distance $=0.0213)$ phases. The percentage of correct classification (which randomly try to classify individuals in males or females based on the mean shape of the group) from the Discriminant Analysis for juveniles was $74.22 \%$ for males and $65.07 \%$ for females, and for adults, it was $89.55 \%$ 
TABLE I

Aegla marginata. Results from the allometric analysis between the body dimensions (dependent variables) and the carapace length (independent variable). AW - abdomen width; CW - carapace width; CL - carapace length; LMA - length of the major cheliped propodus; WMA - width of the major cheliped propodus; LMI - length of the minor cheliped propodus; WMI - width of the minor cheliped propodus; AM - adult males; JM - juvenile males; AF - adult females; JF - juvenile females; $N$ - number of individuals; $\mathbf{r}^{2}$ - determination coefficient; $T$ - $t$ test.

\begin{tabular}{|c|c|c|c|c|c|c|c|}
\hline Variable & Sex & $\mathbf{N}$ & $\begin{array}{c}\text { Inflection } \\
\text { Point }\end{array}$ & Linear equation $(\log Y=\log A+B \cdot \log X)$ & $\mathbf{r}^{2}$ & $T(b=1)$ & Allometry \\
\hline \multirow{4}{*}{ AW } & $\mathrm{AM}$ & 5 & \multirow{2}{*}{18.34} & $\log \mathrm{CL}=-2.9983+3.1976 \log \mathrm{AW}$ & 0.91 & 5.79 & + \\
\hline & $\mathrm{JM}$ & 178 & & $\log C L=-0.3183+1.1572 \log A W$ & 0.99 & 175.13 & + \\
\hline & $\mathrm{AF}$ & 60 & \multirow{2}{*}{10.35} & $\log C L=-0.5546+1.4028 \log \mathrm{AW}$ & 0.94 & 31.59 & + \\
\hline & JF & 82 & & $\log C L=-0.3443+1.2026 \log A W$ & 0.99 & 160.59 & + \\
\hline \multirow{4}{*}{$\mathrm{CW}$} & $\mathrm{AM}$ & 126 & \multirow{2}{*}{7.68} & $\log \mathrm{CL}=-0.1596+1.0079 \log \mathrm{CW}$ & 0.99 & 116.84 & 0 \\
\hline & $\mathrm{JM}$ & 56 & & $\log C L=-0.1535+0.9862 \log C W$ & 0.98 & 58.82 & - \\
\hline & $\mathrm{AF}$ & 92 & \multirow{2}{*}{8.35} & $\log C L=-0.2108+1.0568 \log C W$ & 0.97 & 59.26 & + \\
\hline & JF & 50 & & $\log C L=-0.1798+1.0312 \log C W$ & 0.99 & 116.67 & + \\
\hline \multirow{4}{*}{ LMA } & $\mathrm{AM}$ & 65 & \multirow{2}{*}{10.58} & $\log C L=-0.8452+1.5351 \log \mathrm{LMA}$ & 0.96 & 40.53 & + \\
\hline & JM & 112 & & $\log \mathrm{CL}=-0.3809+1.0798 \log \mathrm{LMA}$ & 0.98 & 102.84 & + \\
\hline & $\mathrm{AF}$ & 124 & \multirow{2}{*}{3.72} & $\log \mathrm{CL}=-0.4033+1.0964 \log \mathrm{LMA}$ & 0.98 & 86.79 & + \\
\hline & JF & 10 & & $\log \mathrm{CL}=-0.3276+1.0219 \log \mathrm{LMA}$ & 0.99 & 29.83 & + \\
\hline \multirow{4}{*}{ WMA } & $\mathrm{AM}$ & 31 & \multirow{2}{*}{4.94} & $\log \mathrm{CL}=-1.2169+1.6173 \log \mathrm{WMA}$ & 0.97 & 76.63 & + \\
\hline & $\mathrm{JM}$ & 151 & & $\log \mathrm{CL}=-0.8654+1.1376 \log \mathrm{WMA}$ & 0.91 & 18.24 & + \\
\hline & $\mathrm{AF}$ & 96 & \multirow{2}{*}{6.59} & $\log C L=-0.8673+1.2263 \log \mathrm{WMA}$ & 0.91 & 31.62 & + \\
\hline & JF & 38 & & $\log \mathrm{CL}=-0.9014+1.2157 \log \mathrm{WMA}$ & 0.97 & 34.87 & + \\
\hline \multirow{4}{*}{ LMI } & $\mathrm{AM}$ & 23 & \multirow{2}{*}{13.12} & $\log C L=-0.4500+1.1660 \log L M I$ & 0.90 & 13.97 & + \\
\hline & $\mathrm{JM}$ & 127 & & $\log C L=-0.4697+1.1593 \log L M I$ & 0.98 & 94.53 & + \\
\hline & $\mathrm{AF}$ & 49 & \multirow{2}{*}{10.39} & $\log C L=-0.6664+1.3180 \log L M I$ & 0.81 & 14.57 & + \\
\hline & JF & 78 & & $\log \mathrm{CL}=-0.3715+1.0433 \log \mathrm{LMI}$ & 0.98 & 67.08 & + \\
\hline \multirow{4}{*}{ WMI } & $\mathrm{AM}$ & 124 & \multirow{2}{*}{5.68} & $\log C L=-1.0615+1.4274 \log \mathrm{WMI}$ & 0.97 & 65.18 & + \\
\hline & $\mathrm{JM}$ & 39 & & $\log C L=-0.8548+1.0771 \log \mathrm{WMI}$ & 0.88 & 17.15 & + \\
\hline & $\mathrm{AF}$ & 90 & \multirow{2}{*}{6.59} & $\log C \mathrm{~L}=-0.8289+1.1708 \log \mathrm{WMI}$ & 0.88 & 25.95 & + \\
\hline & JF & 37 & & $\log C L=-0.9349+1.2425 \log \mathrm{WMI}$ & 0.95 & 28.63 & + \\
\hline
\end{tabular}

\section{TABLE II}

Aegla marginata, Comparison of linear regression parameters between juveniles and adults, based on the covariance analysis (ANCOVA) for both sexes. LMA - length of major cheliped propodus; AW - abdomen width; Df - degrees of freedom; a - intercepts; $b$ - slopes.

\begin{tabular}{ccccccc}
\hline Sex & Dimension & F (a) & F (b) & Df & p (a) & p (b) \\
\hline Males & LMA & 2084.65 & 230.05 & 1.17 & $<0.0001$ & $<0.0001$ \\
Females & AW & 238.98 & 28.87 & 1.13 & $<0.0001$ & 0.0876 \\
\hline
\end{tabular}



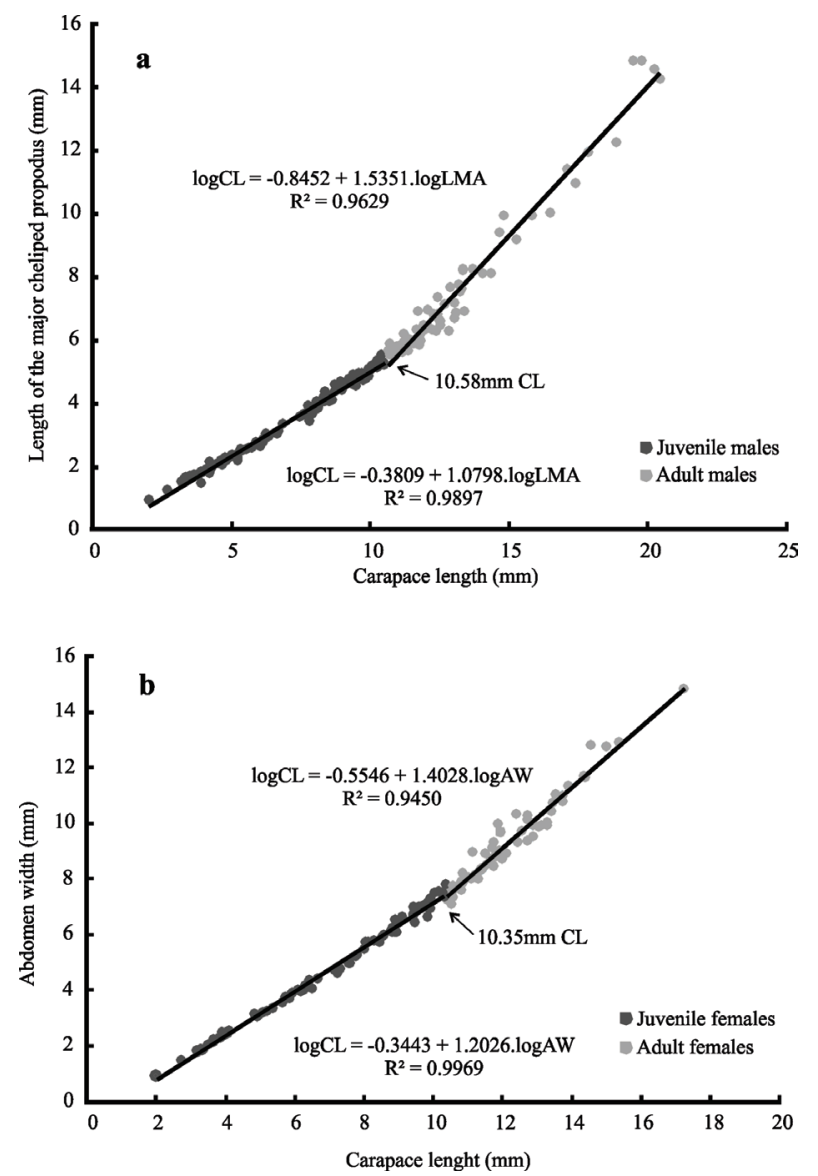

Figure 2 - Aegla marginata. Scatter plot of the empirical points in the relation between the (a) length of the major cheliped propodus (LMA) and the carapace length (CL) of males, and between the (b) abdomen width (AW) and the carapace length (CL) of females. The inflection point is at $10.58 \mathrm{~mm} \mathrm{CL}$ for males and 10.35 for females. Dark circles represent juveniles and light circles adults.

and $82.45 \%$, respectively. In adults, the anatomical landmarks that showed greatest variations were: 1 (tip of the rostrum): females with shorter rostrum; 2 and 11 (tip of the anterolateral spines): shorter spines in females; 4 and 9 (intersection between posterior branchial line and posterior "linea aeglica lateralis"): females with larger carapace; and 5 and 8 (postero-lateral vertex of carapace): females with wider posterior carapace. With the exception of landmarks 4 and 9, the same pattern was observed for juveniles. However, the variation was more evident in adults, indicating that the sexual dimorphism in carapace shape is subtler in the early life stages, despite being statistically significant (Fig. 3). Although we removed animals with damaged rostrum, the variation observed in this structure, and other structures such as thorns, may be occurring because they tend to exhibit strong deformation and are prone to break.

\section{ONTOGENETIC TRAJECTORY}

Ontogenetic allometry was observed in both sexes $(\mathrm{p}<0.001)$. In males, (Procrustes distance -0.0218) the carapace size was responsible for $36 \%$ of shape variation and in females, (Procrustes distance -0.0298 ) for $48.95 \%$. There was a significant difference in the carapace shape between juveniles and adults of both sexes $(\mathrm{p}<0.001)$. Among males, adults showed a slender anterior region of the carapace (landmarks 2 and 11, 3 and 10), a longer rostrum (landmark 1), and a wider posterior region of the carapace (landmarks 5 and 8 ) than the juveniles. A similar pattern was observed in females, however, the widening of the posterior portion of the carapace was more visible (landmarks 5 and 8; 4 and 9) and the elongation of the rostrum was subtler.

The observed angle for the regression vectors between the trajectory of juvenile males and females was $14^{\circ}$, differing significantly from the expected angle $\left(90^{\circ}\right)$ for the random vectors $(\mathrm{p}<0.001)$. In adults, this angle was $66^{\circ}$, not significantly different from the expected angle $\left(90^{\circ}\right)$ for the random vectors $(p=0.12)$. The influence of size on shape variation in juveniles was $42.43 \%$, while in adults it was $1.91 \%$. In juveniles, the allometric trajectory follows a similar direction in both sexes, but it changes in the adult phase and males and females followed through different trajectory directions.

Analysing the sexes separately, the angle between the trajectories of juvenile and adult males was $73^{\circ}$, not differing from the expected for the pairs of random vectors $(p=0.20)$. The size had 


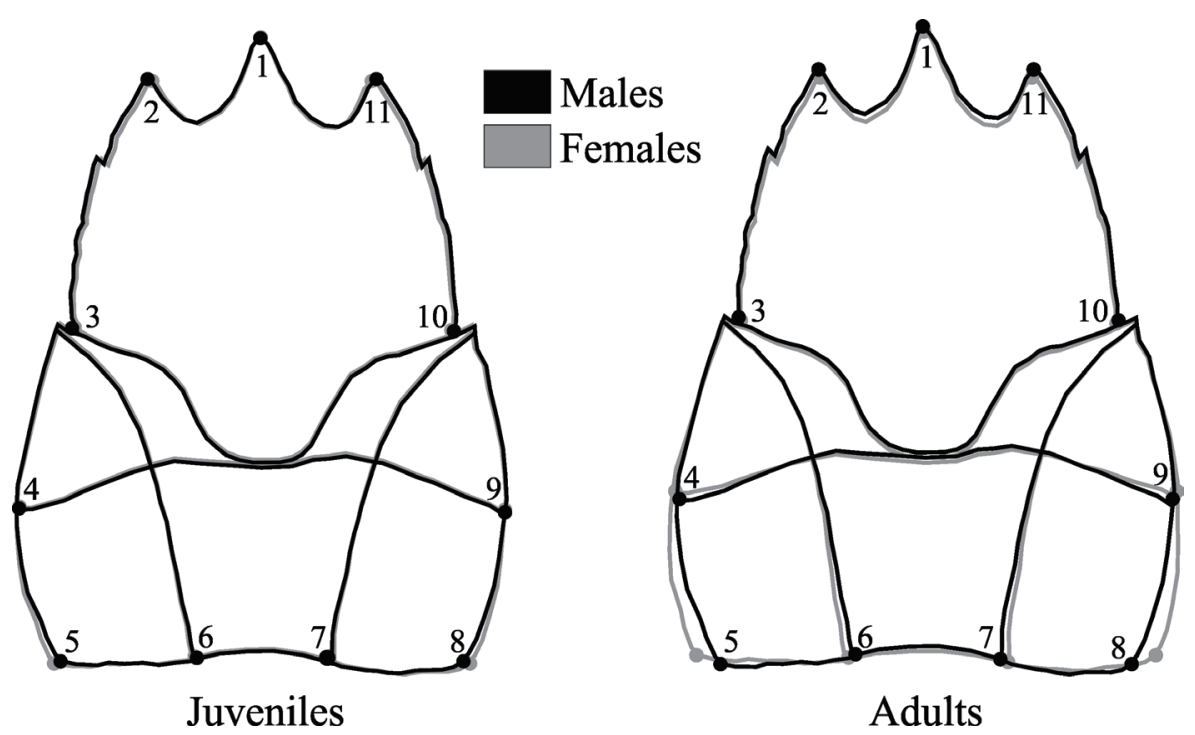

Figura 3 - Aegla marginata. Sexual dimorphism in the carapace shape of juveniles and adults. Deformations magnified 2 times.

an influence of $42.45 \%$ in the shape variation of juveniles and $2.59 \%$ in adults. On the other hand, juvenile and adult females presented a $19^{\circ}$ angle between their trajectories, differing from the expected for the pairs of random vectors $(p<0.001)$. In the juvenile stage, the size explains $45.47 \%$ of the shape variation and in adults $22.06 \%$. Males have divergent directions in their allometric trajectories (Fig. 4a), and females showed similar directions (Fig. 4b).

\section{DISCUSSION}

The dimensions of chelipeds in males and abdomen width in females were the best characters for the determination of the CL in which they attain sexual maturity. Other studies using relative growth to estimate the size at the onset of morphological sexual maturity have also reached the same conclusion (Hartnoll 1983). There is a broad variation in the values of the onset of sexual maturity in aeglids (Table III). Distinct ecological and physical factors can be responsible for the differences in the onset of sexual maturity among different species and populations, such as predator pressure, temperature and photoperiod, food availability, kind of substrate and population density, as observed for brachyurans (Kuris 1971, Wenner et al. 1974, Hines 1989). All those factors could act on the size at the onset of morphological sexual maturity through the modulation of growth rates and longevity (Hines 1989).

In general, aeglid crabs attain sexual maturity when CL is between $38 \%$ and $67 \%$ of the maximum value of CL (Table III), and the lack of consistency in the size on which they reach sexual maturity may be related to life history traits of each population. When facing different selective pressures, populations need to invest their energy to specific functions, since they cannot plenty perform all functions simultaneously (i.e., somatic growth and reproductive tasks) (Llodra 2002). This trade-off can be influenced by environmental conditions at a given time. Animals can invest energy for reproduction at smaller sizes, or they may choose to allocate resources for somatic growth, depending on the dominant selective pressure (Houston and McNamara 1999, Brommer 2000). Therefore, animals that invest in somatic growth before reversing energy for reproductive activities will 

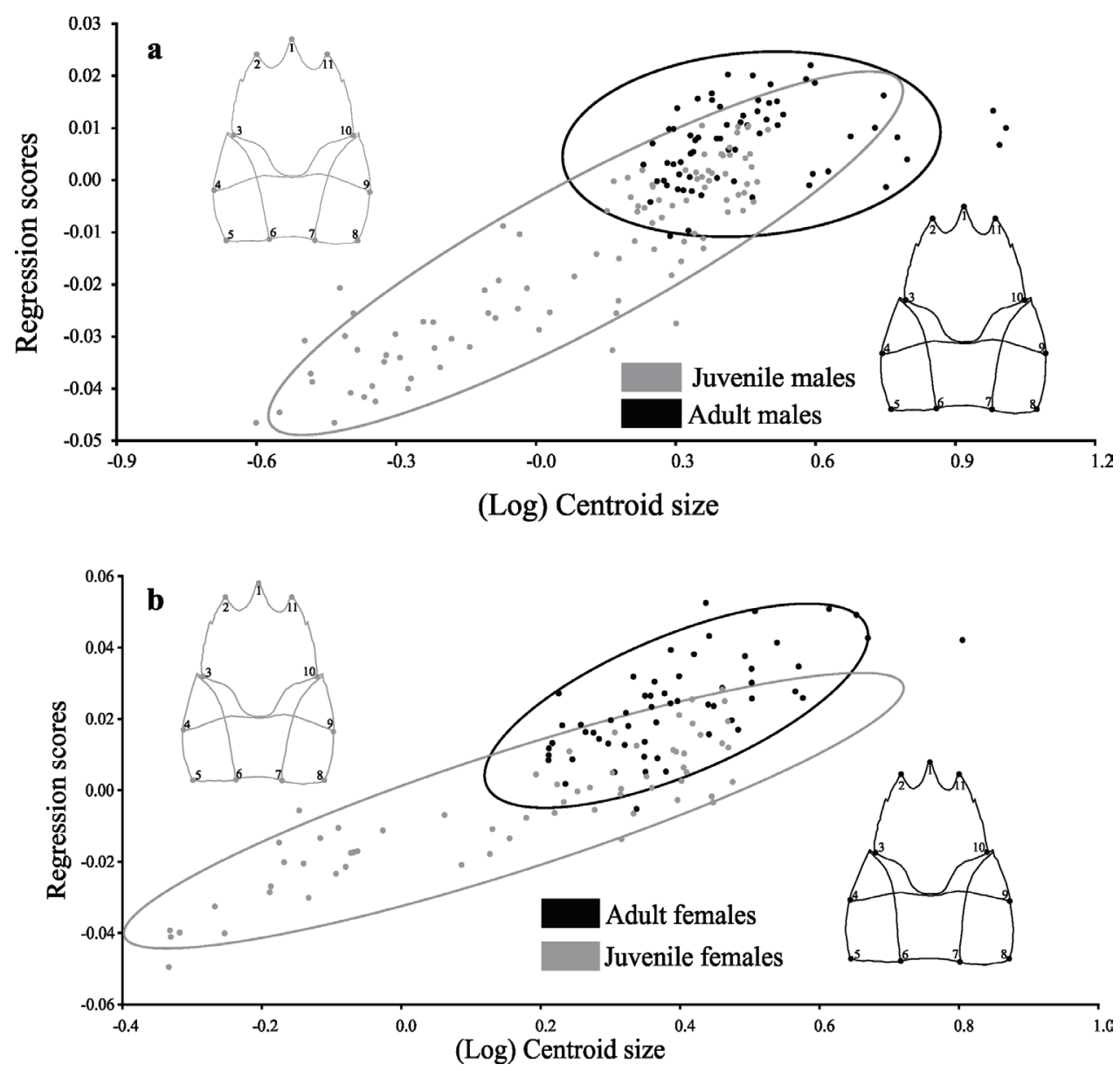

Figure 4 - Aegla marginata. Ontogenetic allometry in (a) male and (b) female carapace shape, based on the multivariate regression of the symmetrical components of shape against logarithmized centroid size.

present larger sizes at the onset of sexual maturity. This indicates that each population is under influence of a specific range of abiotic variables, which can determine the size of sexual maturity. In this sense, populations from environments offering optimal living conditions would reach sexual maturity at higher sizes (Hines 1989). The value obtained for the morphological sexual maturity in females from Barrinha River population (10.38 mm $\mathrm{CL}$ ) was higher than the size of functional maturity (9.2 $\mathrm{mm} \mathrm{CL}$ ) obtained from the Mirante das Antas River, which belongs to the same hydrographic basin (Silva et al. 2016). According to this scenario, it is plausible to assume that the Barrinha River is a more suitable environment for the species, allowing it to reach maturity at a higher size (Table III).

The presence of sexual size dimorphism (SSD) in the adult carapace and absence in juveniles demonstrates that the somatic growth rate in $A$. marginata is similar during the early stages of life. In the adult phase there is an evident change, with males growing at higher rates than females. An inverse pattern has already been observed by Bueno and Bond-Buckup (2000) in Aegla platensis Schmitt, 1942. However, the authors attributed this peculiarity to the rarity of males during the sampling period. In addition, the adult population of $A$. marginata studied by Trevisan et al. (2012), from the Taquaral River, PR, did not exhibit SSD. 
TABLE III

Maximum carapace length (Max. CL) and size of the onset of sexual maturity (OSM) of males and females of aeglid crabs from various localities.

\begin{tabular}{|c|c|c|c|c|c|c|}
\hline Species & River & $\begin{array}{l}\text { Max. CL } \\
\text { males }\end{array}$ & $\begin{array}{c}\text { Max. CL } \\
\text { females }\end{array}$ & $\begin{array}{c}\text { OSM } \\
\text { males } \\
(\mathrm{mm} \mathrm{CL})\end{array}$ & $\begin{array}{c}\text { OSM } \\
\text { females } \\
(\mathrm{mm} \mathrm{CL})\end{array}$ & References \\
\hline Aegla franca & Barro Preto River, MG & - & 18.8 & - & 12.7 & $\begin{array}{c}\text { Bueno and } \\
\text { Shimizu (2008) }\end{array}$ \\
\hline Aegla longirostri & Ibicuí Mirim River, RS & 23.8 & 18.9 & 13.7 & 10.7 & $\begin{array}{l}\text { Colpo et al. } \\
\text { (2005) }\end{array}$ \\
\hline Aegla manuinflata & Taquara River, RS & 27.9 & 24.1 & 14.2 & 13.9 & $\begin{array}{c}\text { Trevisan and } \\
\text { Santos (2012) }\end{array}$ \\
\hline Aegla marginata & Mirante das Antas River, SP & - & 20.0 & - & 9.2 & $\begin{array}{l}\text { Silva et al. } \\
\text { (2015) }\end{array}$ \\
\hline Aegla platensis & Lajeado Bonito River, RS & 31.7 & 27.9 & 21.5 & 16.5 & $\begin{array}{c}\text { Oliveira and } \\
\text { Santos (2011) }\end{array}$ \\
\hline Aegla uruguayana & Areco River, Buenos Aires & 34.7 & 30.1 & 15.4 & 11.6 & Viau et al. (2006) \\
\hline Aegla marginata & Barrinha River, PR & 20.4 & 17.2 & 10.5 & 10.3 & Present study \\
\hline
\end{tabular}

These data suggest that populations of the same species affected by a wide range of abiotic variables may respond differently in terms of its maximum size for each sex.

The sexual shape dimorphism (SShD) in the carapace of $A$. marginata, more pronounced in adults than in juveniles, indicates that the morphological differences between males and females, although present during the initial life stages, becomes marked after sexual maturation. The most evident difference recorded in the present study, the larger posterior region of the carapace in females, seems to be a convergent characteristic in the animal kingdom, that also occurs in lizards (Braña 1996), several mammalian taxa (Glucksmann 1974, Clair 2007, Schutz et al. 2009) and decapod crustaceans (Finney and Abele 1981, Alunno-Bruscia and Sainte-Marie 1998), including aeglids (Barría et al. 2011, Trevisan et al. 2012). The widening of the posterior carapace region follows the expansion of the abdomen, which occurs in females after the transition from the juvenile to the adult phase. This is advantageous to accommodate the egg mass during the incubation period (Hartnoll 1978).
Males and females of $A$. marginata have ontogenetic allometry on the carapace. In both genders, the growth (from juvenile to adult phase) generates a narrowing of the anterior region of the carapace. This pattern is also observed in brachyuran crabs, such as Aratus pisonii Milne Edwards, 1873 and Armases rubripes Rathbun 1897. The study of Marochi (2017) presents a morphological comparison between adult and juvenile stage, arguing that this pattern is common for most decapod crustacean, but that its meaning is not totally understood.

However, the shape variation between juveniles and adults may be related to the differential habitat occupation at each life stage. Juveniles are less active and typically found along the margins of streams, where the substrate is sandier and the water flow is weaker. On the other hand, adults are more active than juveniles, and are usually found in the central area of the stream channel, where a rocky bottom predominates and the water flow is stronger (personal observation). In A. longirostri adults were collected in the river section where the flow rate was stronger and there was predominance of substrate with higher granulometry, while 
juveniles were more abundant in the section where smaller particles predominated (Zimmermann et al. 2016). The drag force generated by the current can dislodge sessile animals and reduce the speed of moving animals (Koehl 1996). Adult aeglids can present intense kinetic activity and move both for and against the current, overcoming physical barriers such as small cascades (Ayres-Peres et al. 2011). In this context, a narrow anterior region of adults may confer more hydrodynamic, making their displacement more efficient by reducing the drag action caused by the current (Nachtigall 1981).

The significant enlargement of the posterior region of the adult females' carapace is related to the abdominal chamber enlargement, previously discussed. This region was dimorphic even in juvenile individuals, although the difference was less pronounced. It seems that morphological variation gradually takes place during the development of aeglids. This supposition is based on the study of Collins et al. (2008), who recorded small shape changes in the reproductive organs from one ecdyses to another, beginning early in the juvenile stage in Aegla uruguayana Schmitt, 1942. This feature is also common in other groups, for example, in rodent females, which present sexual dimorphism in both the shape and size of reproductive structures. This variation also arises in the transition from the juvenile to the adult phase, and is assumed to be caused by sexual hormones (Berdnikovis et al. 2007).

During the juvenile phase, males and females of A. marginata presented similar directions in their allometric trajectories, but they diverged in the adult phase. Therefore, the growth rate during early life stages is similar in both sexes, but undergoes modification during the post maturation stages. The same pattern was observed by Scalici and Gibertini (2009) in crayfishes, and it indicates that after reaching sexual maturity the respective sexual hormones take place, acting differently on the morphology of males and females, especially on secondary sexual characters (cheliped propodus in males and abdomen in females). In addition, the size influenced almost $50 \%$ of the carapace shape variation in the juvenile phase, but had practically null influence in the adult phase. This pattern seems to be related to the relative growth in crustaceans, and according to Hartnoll (1983), there are more ecdyses and significant increase in size during the early stages of life. These data indicate that the juvenile shape changes more drastically at each ecdysis and, therefore, size is a determining factor in its morphology. However, among adults these changes are not expressive.

\section{CONCLUSIONS}

The sexual dimorphism in size and shape found in Aegla marginata seems to be related, respectively, to the reproductive traits and to the secondary sexual characteristics of the species. On the other hand, the shape variations between juveniles and adults may be related to spatial distribution traits, with respect to differential habitat occupation by these life stages. Our results indicate that $A$. marginata does not undergo an abrupt change in its morphology at a certain stage of its development. Differences in the carapace shape between sexes appear and intensify gradually during the species ontogeny.

Our study provides important information about the morphological variation in $A$. marginata, which was intended to partially understand its evolutionary history. In future studies, it is essential to analyze morphological variation not only on the carapace, but also on other body structures, such as chelipeds, during the ontogeny of $A$. marginata and other congenerics. These results will bring a broader understanding of the factors influencing the morphology of the genus.

\section{ACKNOWLEDGMENTS}

We are thankful to MSc. Renata Daldin Leite and MSc. Madson Silveira Melo for field assistance and 
Dr. Mauricio Osvaldo Moura from Universidade Federal do Paraná and Dr. Sandro Santos from Universidade Federal de Santa Maria for comments that greatly improved the manuscript. Thanks are also due to Coordenação de Aperfeiçoamento de Pessoal de Nível Superior (CAPES) and Conselho Nacional de Desenvolvimento Científico e Tecnológico (CNPq) for scholarship granted for the first and second authors. This is Contribution No. 1952 of the Departamento de Zoologia, Universidade Federal do Paraná.

\section{REFERENCES}

ADAMS DC, ROHLF FJ AND SLICE DE. 2004. Geometric morphometrics: ten years of progress following the 'revolution'. Ital J Zool 71(1): 5-16.

ALUNNO-BRUSCIA M AND SAINTE-MARIE B. 1998. Abdomen allometry, ovary development, and growth of female snow crab, Chionoecetes opilio (Brachyura, Majidae), in the northwestern Gulf of St. Lawrence. Can J Fish Aquat Sci 55(2): 459-477.

AYRES M, AYRES JR M, AYRES DL AND SANTOS AS. 2007. Bioestat Versão 5.0. Belém: Sociedade Civil Mamirauá, MCT-CNPq.

AYRES-PERES L, COUTINHO C, BAUMART JS, GONÇALVES AS, ARAUJO PB AND SANTOS S. 2011. Radio-telemetry techniques in the study of displacement of freshwater anomurans. Nauplius 19(1): 41-54.

BARRÍA EM, SEPÚLVEDA RD AND JARA CG. 2011. Morphologic variation in Aegla Leach (Decapoda: Reptantia: Aeglidae) from central-southern Chile: interspecific differences, sexual dimorphism, and spatial segregation. J Crustacean Biol 31(2): 231-239.

BERDNIKOVS S, BERNSTEIN M, METZLER A AND GERMAN RZ. 2007. Pelvic growth: Ontogeny of size and shape sexual dimorphism in rat pelves. J Morphol 268(1): 12-22.

BRAÑA F. 1996. Sexual dimorphism in lacertid lizards: male head increase vs. female abdomen incresde? Oikos 75: 511-523.

BROMMER JE. 2000. The evolution of fitness in life-history theory. Biol Rev 75(3): 377-404.

BUENO AADP AND BOND-BUCKUP G. 2000. Population's dynaniics of Aegla platensis Schmitt (Crustácea, Decapoda, Aeglidae). Rev Bras Zool 17(1): 43-49.

BUENO SL AND SHIMIZU RM. 2008. Reproductive biology and functional maturity in females of Aegla franca (Decapoda: Anomura: Aeglidae). J Crustacean Biol 28(4): 652-662.
CLAIR EMS. 2007. Sexual dimorphism in the pelvis of Microcebus. Int J Primatol 28(5): 1109-1122.

COCK AG. 1966. Genetical aspects of metrical growth and form in animals. Q Rev Biol 41(2): 131-190.

COLLINS PA, GIRI F AND WILLINER V. 2008. Sexual maturity and ontogenetic shape variations in the freshwater anomuran crab, Aegla uruguayana (Decapoda, Aeglidae). Invertebr Reprod Dev 52(1-2): 113-119.

COLPO KD, RIBEIRO LO AND SANTOS S. 2005. Population biology of the freshwater anomuran Aegla longirostri (Aeglidae) from south Brazilian streams. J Crustacean Biol 25(3): 495-499.

CRANE J. 1966. Combat, display and ritualization in fiddler crabs (Ocypodidae, genus Uca). Philos T Roy Soc B 251(772): 459-472.

DRAKE AG AND KLINGENBERG CP. 2008. The pace of morphological change: historical transformation of skull shape in St Bernard dogs. Proc Royal Soc Lond B: Biol Sci 275(1630): 71-76.

FAIRBAIRN DJ. 1997. Allometry for sexual size dimorphism: pattern and process in the coevolution of body size in males and females. Annu Rev Ecol Syst 28: 659-687.

FINNEY WC AND ABELE LG. 1981. Allometric variation and sexual maturity in the obligate coral commensal Trapezia ferruginea Latreille (Decapoda, Xanthidae). Crustaceana 41(2): 113-130.

GIRI F AND COLLINS PA. 2004. A geometric morphometric analysis of two sympatric species of the family Aeglidae (Crustacea, Decapoda, Anomura) from the La Plata basin. Ital J Zool 71(1): 85-88.

GLUCKSMANN A. 1974. Sexual dimorphism in mammals. Biol Rev 49(4): 423-475.

HARTNOLL RG. 1974. Variation in growth pattern between some secondary sexual characters in crabs (Decapoda Brachyura). Crustaceana 27(2): 131-136.

HARTNOLL RG. 1978. The determination of relative growth in Crustacea. Crustaceana 34(3): 281-293.

HARTNOLL RG. 1983. Strategies of crustacean growth. Australian Museum Memoirs 18: 121-131.

HARTNOLL RG. 2001. Growth in Crustacea: twenty years on. Hydrobiologia 449(1): 111-122.

HEDRICK AV AND TEMELES EJ. 1989. The evolution of sexual dimorphism in animals: hypotheses and tests. Trends Ecol Evol 4(5): 136-138.

HEPP LU, FORNEL R, RESTELLO RM, TREVISAN A AND SANTOS S. 2012. Intraspecific morphological variation in a freshwater crustacean Aegla plana in Southern Brazil: effects of geographical isolation on carapace shape. J Crustacean Biol 32(4): 511-518.

HINES AH. 1989. Geographic variation in size at maturity in brachyuran crabs. B Mar Sci 45(2): 356-368. 
HOUSTON AI AND MCNAMARA JM. 1999. Models of adaptive behaviour: an approach based on state. Cambridge University Presss, 390 p.

HUXLEY JS. 1950. Relative growth and form transformation. Proc Royal Soc Lond 137(B): 465-469.

KENDALL DG. 1977. The diffusion of shape. Adv Appl Probab 9(3): 428-430.

KLINGENBERG CP. 1996. Multivariate allometry. In: Marcus LF, Corti M, Loy A, Naylor GJP and Slice DE (Eds), Advances in Morphometrics, Springer US, p. 23-49.

KLINGENBERG CP. 2011. MorphoJ: an integrated software package for geometric morphometrics. Mol Ecol Resour 11(2): 353-357.

KLINGENBERG CP. 2016. Size, shape, and form: concepts of allometry in geometric morphometrics. Dev Genes Evol $1-25$.

KLINGENBERG CP AND MONTEIRO LR. 2005. Distances and directions in multidimensional shape spaces: implications for morphometric applications. Systematic Biology 54: 678-688.

KOEHL MAR. 1996. When does morphology matter? Annu Rev Ecol Syst 27(1): 501-542.

KURIS AM. 1971. Population interactions between a shore crab and two symbionts. Ph.D. Dissertation, University of California, Berkeley, $451 \mathrm{p}$.

LLODRA ER. 2002. Fecundity and life-history strategies in marine invertebrates. Adv Mar Biol 43: 87-170.

MAACK R. 1981. Geografia física do Estado do Paraná. Paraná: J Olympio, 450 p.

MAROCHI MZ. 2017. Variabilidade morfológica, genética, ontogenia e fisiologia de caranguejos semi-terrestres estuarinos (Crustacea, Decapoda, Sesarmidae). Universidade Federal do Paraná, Programa de PósGraduação em Zoologia. Tese de Doutorado, 188 p.

MAROCHI MZ, TREVISAN A, GOMES FB AND MASUNARI S. 2016. Sexual dimorphism in Hepatus pudibundus (Crustacea, Decapoda: Brachyura). Iheringia 106: $1-6$.

MITTEROECKER P, GUNZ P, WINDHAGER S AND SCHAEFER K. 2013. A brief review of shape, form, and allometry in geometric morphometrics, with applications to human facial morphology. Hystrix, Ital J Mammalogy 24(1): 59-66.

NACHTIGALL W. 1981. Hydromechanics and biology. Biophysics of structure and mechanism 8(1-2): 1-22.

OLIVEIRA DD AND SANTOS S. 2011. Morphological sexual maturity of Aegla platensis (Crustacea, Decapoda, Anomura) in the Lajeado Bonito, north of the State of Rio Grande do Sul, Brazil. Iheringia. Série Zoologia 101(1-2): 127-130.
PEZZUTO PR. 1993. Regrans: a "basic" program for an extensive analysis of relative growth. Atlântica 15: 93-105.

R DEVELOPMENT CORE TEAM. 2008. R: a language and environment for statistical computing. R Fundation for Statistical Computing, Vienna, Austria.

ROHLF FJ. 2010. tpsDig v 2.16. Department of Ecology and Evolution, State University of New York, Stony Brook, New York.

SCALICI M AND GIBERTINI G. 2009. Sexual dimorphism and ontogenetic variation in the carapace of $A$. pallipes (Lereboullet, 1858). Ital J Zool 76(2): 179-188.

SCHUTZ H, DONOVAN ER AND HAYES JP. 2009. Effects of parity on pelvic size and shape dimorphism in Mus. J Morphol 270(7): 834-842.

SHINE R. 1989. Ecological causes for the evolution of sexual dimorphism: a review of the evidence. Q Rev Biol 64(4): 419-461.

SILVA AR, WOLF MR AND CASTILHO AL. 2016. Reproduction, growth and longevity of the endemic South American crab Aegla marginata (Decapoda: Anomura: Aeglidae). Invertebra Reprod Dev 60(1): 59-72.

SOKAL RR AND ROHLF JF. 1979. Biometry. New York: Freeman, $887 \mathrm{p}$.

TREVISAN A, MAROCHI MZ, COSTA M, SANTOS S AND MASUNARI S. 2012. Sexual dimorphism in Aegla marginata (Decapoda: Anomura). Nauplius 20(1): 75-86.

TREVISAN A AND SANTOS S. 2012. Morphological sexual maturity, sexual dimorphism and heterochely in Aegla manuinflata (Anomura). J Crustacean Biol 32(4): 519-527.

VENTURA T, ROSEN O AND SAGI A. 2011. From the discovery of the crustacean androgenic gland to the insulinlike hormone in six decades. Gen Comp Endocr 173(3): 381-388.

VIAU VE, LÓPEZ-GRECO LS, BOND-BUCKUP G AND RODRÍGUEZ EM. 2006. Size at the onset of sexual maturity in the anomuran crab, Aegla uruguayana (Aeglidae). Acta Zool 87(4): 253-264.

VISCOSI V AND CARDINI A. 2011. Leaf morphology, taxonomy and geometric morphometrics: a simplified protocol for beginners. PLoS ONE 6(10): e25630.

WENNER AM, FUSARO C AND OATEN A. 1974. Size at onset of sexual maturity and growth rate in crustacean populations. Can J Zool 52(9): 1095-1106.

ZIMMERMANN BL, DAMBROS CS AND SANTOS S. 2016. Association of microhabitat variables with the abundance and distribution of two neotropical freshwater decapods (Anomura: Brachyura). J Crustacean Biol 36(2): 198-204. 